Research Article

\title{
Nonlinear Characteristics of the Effect of Manufacturing Servitization on Consumer Business Performance
}

\author{
Guoqiong Long, ${ }^{1}$ Chong $\mathrm{Li}$ iD, ${ }^{1,2}$ Shuai $\mathrm{Li}^{2}$ and Tianxiang $\mathrm{Xu}^{1}$ \\ ${ }^{1}$ School of Economics, Yunnan University of Finance and Economics, Kunming 650221, Yunnan, China \\ ${ }^{2}$ School of Economics, Yunnan University, Kunming 650331, Yunnan, China \\ Correspondence should be addressed to Chong Li; lichong@ynufe.edu.cn
}

Received 9 October 2021; Revised 2 November 2021; Accepted 16 November 2021; Published 29 November 2021

Academic Editor: Sang-Bing Tsai

Copyright (C) 2021 Guoqiong Long et al. This is an open access article distributed under the Creative Commons Attribution License, which permits unrestricted use, distribution, and reproduction in any medium, provided the original work is properly cited.

\begin{abstract}
Servitization is an important trend in the transformation and upgrading of the manufacturing industry, but whether it can significantly improve enterprise performance is the key to the transformation. Based on the sample of Chinese A-share listed companies from 2011 to 2019 , we analyze the business scope of 2502 annual reports to identify the service level of consumer goods manufacturing enterprises. The results show the following. (1) The "service performance" curve shows obvious nonlinear trends and heterogeneity in different industries and different performance conditions. The curve between servitization and return on assets tends to show a positive " $U$ " shape, but the relationship between servitization and revenue per employee obviously shows an inverted "U" shape. (2) Manufacturing enterprises with relatively low technical complexity and relatively high industry competition will reach the inflection point of service performance " $U$ " curve more quickly and get rid of "service trap" more easily. (3) The automobile manufacturing industry invests in software development and other fields that are not related to its own advantages, which violates the correlation law of the industrial value chain, leading to the coexistence of "service trap" and "principle-agent dilemma." The clothing and electrical appliances industries are more likely to fall into the "service trap" because they face the challenge of "Internet + manufacturing" transformation. The beverage and wine manufacturing industry has induced a "service spillover" effect, which is mainly due to its low technical complexity and service based on the industrial chain. It is proposed that manufacturing enterprises explore business growth points from the perspective of industrial value chain extension and strengthen upstream product $\mathrm{R} \& \mathrm{D}$ and terminal e-commerce services.
\end{abstract}

\section{Introduction}

Economic servicing is the general law of the evolution of industrial structure. Manufacturing service is an important trend of economic servitization and the key to guiding the national manufacturing industry towards more advancement and upgrading. In the era of digital economy, the popularization of information and communication technology has created new conditions for the integration of manufacturing and service industries. The "Made in China 2025 " strategic policy clearly pointed out that all provinces should promote the transformation of China's productionoriented manufacturing to service-oriented manufacturing. The manufacturing of consumer goods is a market link in the industrial value chain, which has always driven the upgrading of the manufacturing industry. According to theory of social reproduction, in the relationship between production and consumption, production determines consumption, while consumption reacts to production, and consumption is the starting point of reproduction activities. The two-wheel drive of "manufacturing + service" is the integration of product economy based on production and service economy based on consumption.

Since Vandermerwe and Rada [1] put forward the concept of manufacturing service, that is, the process of service innovation in which manufacturing enterprises provide supporting service packages in the process of product R\&D and production, service has been widely 
emphasized as the main source of product value-added. Firstly, the service-oriented manufacturing enterprise aims to solve the consumption problem and create service value by using information network technology and e-commerce means, which can reduce the pressure of marginal profit compression of mature industries or products to a certain extent, and avoid or overcome the fierce competition and uncertainty from low-cost economy [2, 3]. Secondly, judging the success of enterprise service transformation strategy depends more on the improvement of enterprise business performance. Theoretically, the service-oriented transformation of manufacturing en terprises can exert economies of scope and differentiated premium effects, which can lead to better performance $[4,5]$. However, there are numerous empirical facts in the literature that show that the performance spillover effect of service-oriented manufacturing is generally lower than the enterprise expectation, and the relationship between service-oriented manufacturing and enterprise performance is not stable. There may be characteristics such as negative, " $U$ " shape, and inverted " $U$ " shape relationship and even realistic conclusions including multistage nonlinear characteristics [6-9]. The purpose of enterprise servitization is to obtain positive performance impact. This positive impact is called "service spillover." When enterprise servitization brings negative benefits, it is called a "service trap." In addition, Xiao et al. [10] studied the "service performance" curve of food, textile, transportation, and electronic equipment industries from the perspective of industry and found that there is a bottom inflection point of service trap. Therefore, the relationship between manufacturing service and enterprise performance is not a linear development feature in theory, and there should be industry heterogeneity.

The existing literature studies mainly focus on the curvilinear relationship between service industry and performance from the perspectives of different institutional countries, different enterprise characteristics, different service supply chain, different external network relations, and different customer demand orientation [11-16] and lack of attention to heterogeneous enterprises in consumer manufacturing industry. Firstly, due to the differences in industrial technology complexity and competition level, manufacturing enterprises implementing the same serviceoriented strategy may not produce the same effect. Secondly, the literature on manufacturing service strategy and enterprise performance does not precisely reveal the internal mechanism of "service dilemma." Moreover, the evaluation of enterprise performance is a relatively complex system engineering. If only a single index is used for measurement, there may be misjudgment and incomplete statistics of performance effect. Finally, China's consumption structure has altered from material consumption to service consumption, and the service-oriented transformation of consumer goods manufacturing industry has begun to take effect. The analysis of typical characteristics of consumer goods manufacturing enterprises can not only provide a reference basis for the performance spillover effect of service-oriented current basic consumer goods manufacturing industry, but also provide reference for the high-end service transformation of equipment manufacturing industry rich in technology.

The paper proceeds as follows: Section 2 states the literature review and hypothesis development. Section 3 describes methodology and data. Section 4 presents empirical analysis. Section 5 carries out the scenario test of different attributes and the analysis of the internal mechanism. Section 6 discusses the research outcomes and concludes the paper.

\section{Literature Review and Hypothesis Development}

2.1. Industry, Objectives, and Performance. Consumer goods manufacturing enterprises provide consumers with a more complete "portfolio" of products and services through the implementation of service-oriented strategy and gradually establish differentiated competitive advantages and customer satisfaction, which can bring higher and more stable sources of income and profit for enterprises. The development of enterprise performance is the ultimate goal of enterprise advocating service-oriented strategy $[4,16,17]$. However, many literature studies show that, in the process of service-oriented manufacturing enterprises not only do not obtain the performance spillover effect of service-oriented manufacturing, but also fall into the "service-oriented trap," that is, service-oriented manufacturing has a negative impact on enterprise performance.

Weng et al. [18] believe that the relationship between China's manufacturing service and enterprise performance is still on the left side of the positive " $U$ " curve, and the inflection point has not yet arrived. Xiao [19] believes that enterprises are more likely to fall into the "service profit trap" in the early stage of service-oriented business, and it usually takes several years to obtain service-oriented performance benefits. When carrying out the service-oriented strategy, the enterprise should change the original organization to adapt to the service-oriented business, such as establishing a new department, recruiting new employees, investing in new equipment, integrating new resources, etc. The enterprise will face a large consumption of cash flow and a significant increase in management costs, as well as the risks of organization, management, and marketing, which will inhibit the improvement of enterprise performance, resulting in "service-oriented dilemma." However, with the advancement of the service-oriented process, enterprises that obtain competitive advantage in the service-oriented reform will gradually obtain the positive effect of scope economy, break away from the "service-oriented dilemma," and win the scale effect. At this time, the spillover effect of service-oriented performance shows a positive " $U$ " dynamic trend of first declining and then rising.

However, other scholars such as Chen [3], Kohtamaki et al. [20], and Suarez et al. [21] believe that although serviceoriented manufacturing enterprises can achieve positive performance promotion effect in the short term, it will be inhibited by the principal-agent management mechanism in the long term. In the principal-agent management mechanism, the ownership and management rights of enterprises 
are separated. Senior managers are professional managers. They are vulnerable to the realization of personal utility goals, such as wealth, status, and preference, rashly expand to unfamiliar or even unrelated service fields, and excessively disperse resources, resulting in the decline of enterprise performance, and this phenomenon is called the "principalagent dilemma." Chen [3] believes that in the early stage of service-oriented manufacturing enterprises are more likely to be widely concerned with the market, so as to obtain the competitive advantage of the same industry, and enterprise performance can be improved rapidly. However, with the deepening of service-oriented degree and the intensification of market competition, enterprise performance will decline. That is, the spillover effect of service-oriented manufacturing on performance presents an inverted " $U$ " dynamic change characteristic of "first rising and then falling."

If we only analyze the consumer manufacturing industry, in general, the "service performance" curve of the manufacturing industry with increasing returns to scale tends to show the characteristics of "first declining and then rising." On the contrary, the manufacturing industry with diminishing returns to scale will show the characteristics of the inverted " $U$ " curve [22]. Therefore, when examining the spillover effect of manufacturing service, this paper needs to consider the heterogeneity of the industry. In addition, in different performance indicators, there are obvious differences in the path and effect of servitization [23, 24]. On the one hand, the return on assets is used to express the financial performance of enterprises, mainly to measure the profitability of enterprises from the perspective of assets $[25,26]$. In the initial stage of service-oriented manufacturing, the focus of enterprises has shifted from the hard factors at the functional level such as the technical characteristics or quality of products to the soft elements at the service level such as product customization and experience. Basic consumer manufacturing enterprises will compete with upstream and downstream service providers, which will increase costs and show a decline in financial performance $[27,28]$. When the service degree of manufacturing enterprises matches with the soft elements of service level, their financial performance will show an upward trend with the increase of service. The return on investment in the initial stage of service-oriented enterprise is not achieved overnight. It takes sufficient time to adapt to the servicing business.

On the other hand, the revenue per employee is used to express enterprise employee performance, which is mainly to measure enterprise profitability from the perspective of human resources. In the early stage of service-oriented manufacturing, consumer manufacturing enterprises do not have high requirements for employee knowledge reserve. The existing human resources can meet the service-oriented business needs, and service-oriented manufacturing can temporarily improve and improve employee performance. However, in the mature period of service, in order to obtain scale effect, enterprises need to invest a lot of human resources, and there will be the problem of principal-agent management $[4,29]$. At the same time, the time management system of the service department is more prone to principal-agent problems than the piece work management system of the production department [30]. Therefore, the existence of the principal-agent management mechanism tends to reduce the performance of human resources in enterprises for a long time. Therefore, we hypothesize the following

Hypothesis 1. The "service performance" curve of manufacturing enterprises shows nonlinear trends and heterogeneity in different industries and different performance objectives.

Hypothesis 1a: the curve of "service orientation and return on assets" of consumer goods manufacturing enterprises tends to show a positive U-shape.

Hypothesis 1b: the curve of "service orientation and revenue per employee" of consumer goods manufacturing enterprises tends to show an inverted U-shape.

2.2. External Environment and Performance. In addition, due to the differences in industrial technology complexity and competition, even if the manufacturing enterprises facing end consumption implement the same service-oriented strategy, it may not produce the same effect. According to the research of Xia and $\mathrm{Hu}$ [31], the higher the service technology level of manufacturing products, the greater the difficulty of service technology development, the higher the service investment, the greater the innovation risk, and the slower the service performance inflection point shows [32]. Therefore, it can be preliminarily judged that enterprise performance inflection point brought by the implementation of low-end service in the consumer goods manufacturing industry is easier to appear. On the contrary, enterprise performance inflection point of high-end serviceoriented consumer goods manufacturing industry will appear slower. From the perspective of the internal competitive environment of the industry, the greater the degree of internal competition, the faster the iteration speed of products. Coupled with consumption upgrading, the products provided by manufacturing enterprises can better meet the differentiated, diversified, and quality needs of consumers, diversification, and quality. After the survival of the fittest, enterprises tend to show better income performance and enhance their own performance quickly. The inflection point of the service performance relationship curve can often appear faster. Therefore, we hypothesize the following:

Hypothesis 2. The performance effects of service-oriented manufacturing enterprises are different under the conditions of different technical levels and different competitive environments.

Hypothesis 2a: At a certain industry technical level, the consumer goods manufacturing industry with relatively low technical complexity tends to display the inflection point of the service performance " $U$ " relationship curve faster.

Hypothesis 2 b: In a certain industry competition environment, the consumer goods manufacturing 
industry with relatively high industry competition tends to display the inflection point of the service performance "U" relationship curve faster.

\section{Methodology and Data}

3.1. Sample and Data. We selected listed companies in basic consumer manufacturing from 2011 to 2019 as the research sample. Firstly, according to the industry classification code of the China Securities Regulatory Commission, the consumer manufacturing industry is divided into five subcategories: clothing, beverage, automobile, medicine, and electrical appliances. Secondly, the furniture manufacturing industry and paper manufacturing industry with insufficient samples are excluded. Finally, special treatment enterprises and enterprises without service business are excluded. After screening according to the above conditions, a total of 278 companies were selected, including 27, 75, 29, 25, and 122 in clothing, electrical appliances, beverages and wine, automobile, and medicine, respectively, as shown in Table 1 . The variables obtained totaled 2502 observation samples and 15012 effective observation values. The data of all variables are from CSMAR (China Stock Market \& Accounting Research Database), Wind Economic database, and the annual financial reports of listed companies.

According to the survey data, manufacturing enterprises of different consumption types have different degrees and links of service. For example, the clothing industry has a high degree of integration in the middle and lower reaches of warehousing, logistics, and e-commerce sales, such as Jiaxin Silk, Metersbonwe clothing, Joeone, Modern Avenue, Mailyard, Toread, etc.; the electrical and automobile manufacturing industries have made remarkable progress in design and R\&D, such as Midea Group, Vantage, Changgao group, FAW sedan, BYD, SAIC, etc. As shown in Figure 1, the reverse guiding effect of e-commerce in consumer manufacturing enterprises on enterprise product $R \& D$, production mode, organization, and management is not well reflected. It should be noted that the current e-commerce of consumer manufacturing companies is mainly concentrated on the sales side to achieve the goals of expanding sales, handling inventory, and reducing sales (transaction) costs, while reducing production and manufacturing costs $[33,34]$, optimizing product design, and improving products and services are still in the initial application stage. Giving full play to the value of e-commerce in the design and production process is the main trend of e-commerce development in the future.

\subsection{Variables}

\subsubsection{Core Variables}

(1) Service degree (SED). Referring to the practice of Kastalli and Van Looy [35], the degree of service is expressed as the scope of service business operated by manufacturing enterprises and the degree of meeting the needs of consumers. Alrneida et al. [36] demonstrated the decision-making model of service-oriented transformation of manufacturing industry which includes information technology, e-commerce, and networking. Further, referring to Neely [8], enterprise operation services are mainly divided into ten types: e-commerce, consulting and training, design and $\mathrm{R} \& \mathrm{D}$, finance, contracted operation, after-sales, import and export, consignment sales, leasing services, and logistics warehousing. This article performs word frequency statistical analysis on the description texts of the business scope of listed companies and summarizes the frequency of repeated or similar keywords to form enterprise service data. The word frequency data is usually right-biased, and the service data is processed logarithmically. (2) Enterprise performance (ROA, RPE). Firstly, it is proposed to measure the financial performance of enterprises by using the index return on assets (ROA), which is widely used by scholars at present. The profitability of enterprise assets is expressed by the ratio of net profit to total assets. Secondly, the revenue per employee (RPE) is introduced as a variable to measure the per employee business performance of enterprises, which is expressed by the ratio of enterprise revenue to total employees. Because revenue per employee has an increasing trend, logarithmic processing is carried out to obtain more scientific results.

3.2.2. Control Variables. (1) Labor element structure (LES). The change of labor factor structure reflects the change of enterprise personnel structure caused by the increase of service business in the process of manufacturing service. This paper uses the change of the proportion of employees with college degrees or above to represent the change of labor factor structure. (2) Degree of market monopoly (DMM). The market power of an enterprise is a key indicator to measure the competitive environment of an enterprise. It is measured by the improved Lerner Index. The Lerner Index essentially reflects the incremental gross profit margin. Therefore, it is calculated by subtracting the main business cost from the main business income and dividing it by the main business income based on the practice of Zhang [37]. (3) Enterprise development scale (EDS). The development scale of the enterprise itself is widely regarded as an important variable affecting performance. The size of the enterprise is closely related to the development of the enterprise, which is expressed by the natural logarithm of the total assets at the end of the period.

3.3. Model Construction. This paper focuses on the impact of end consumption oriented manufacturing service on enterprise performance and refers to Neely [8] to measure the degree of service (SED) from the business scope of the enterprise to explore its impact on the return on assets (ROA) and revenue per employee (RPE). Based on this, we constructed the following regression model:

$$
\mathrm{MP}_{i, t}\left(\mathrm{Rph}_{i, t} ; \operatorname{Roa}_{i, t}\right)=\alpha_{0}+\beta_{1} \mathrm{SED}_{i, t}+\sum_{k} a_{k} X_{k}+\gamma_{i}+\lambda_{t}+\varepsilon_{i . t} .
$$


TABLE 1: Variable descriptions.

\begin{tabular}{|c|c|c|c|c|c|c|}
\hline Variables & Variable definitions & Obs & Mean & Std & Min & Max \\
\hline SED (service degree) & $\begin{array}{c}\text { The natural log of (number of service-oriented businesses of the } \\
\text { enterprise) }\end{array}$ & 2502 & 0.6203 & 0.1781 & 0.000 & 1.000 \\
\hline RPE (revenue per employee) & The natural log of (enterprise revenue/total employees) & 2502 & 1.890 & 0.315 & 0.269 & 3.913 \\
\hline ROA & Net profit after & 2502 & & & -0 . & 0.479 \\
\hline LES & Proportion of employ & 2502 & 0.243 & 0.155 & 0.017 & 0.877 \\
\hline $\begin{array}{l}\text { DMM (degree of market } \\
\text { monopoly) }\end{array}$ & $\begin{array}{l}\text { (Main business income-main business cost)/Main business } \\
\text { income }\end{array}$ & 2502 & 0.146 & 0.202 & 0.001 & 7.541 \\
\hline $\begin{array}{l}\text { EDS (enterprise development } \\
\text { scale) }\end{array}$ & The natural $\log$ of total assets at the end of the period & 2502 & 22.146 & 1.129 & 24.778 & 17.705 \\
\hline $\begin{array}{l}\text { DIC (degree of industry } \\
\text { competition) }\end{array}$ & Herfindahl-Hirschman Index & 45 & 0.0814 & 0.012 & 0.011 & 0.028 \\
\hline $\begin{array}{l}\text { ITC (industry technical } \\
\text { complexity) }\end{array}$ & Complete consumption coefficient of manufacturing service & 45 & 0.0352 & 0.018 & 0.022 & 0.049 \\
\hline
\end{tabular}

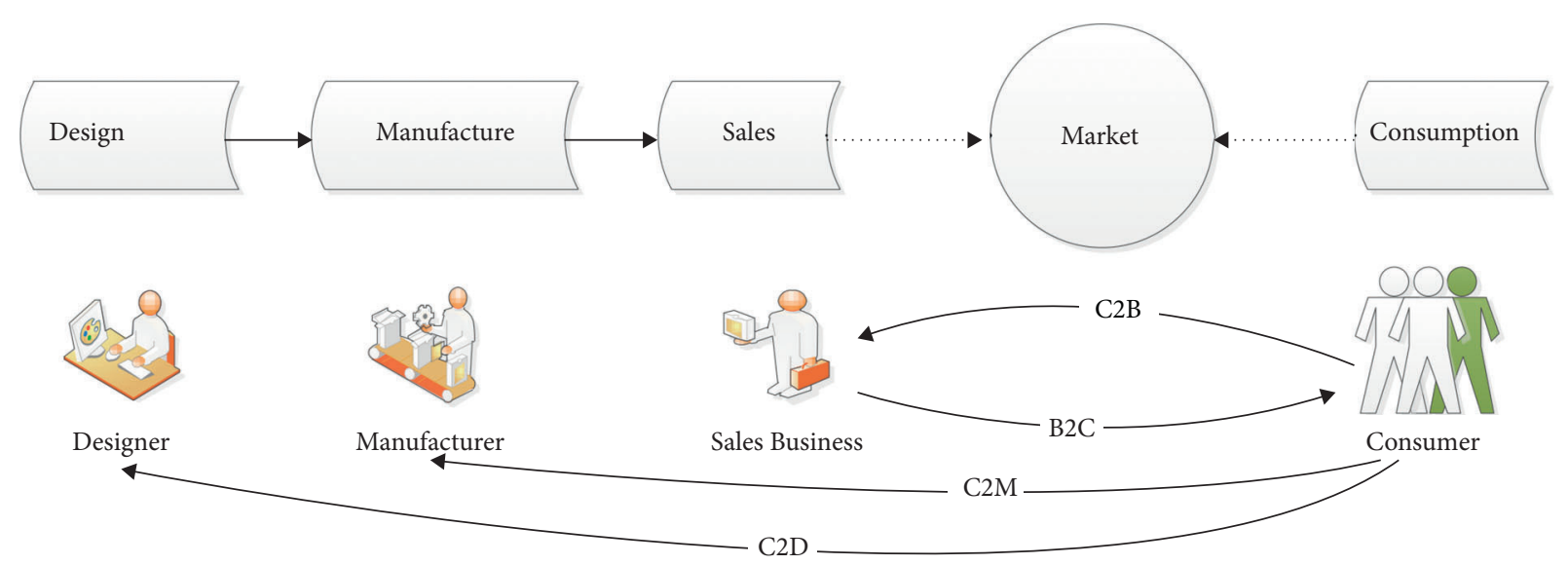

FIGURE 1: Evolution path of manufacturing service.

$\mathrm{MP}_{i, t}$ represents enterprise performance, including return on assets (ROA) and revenue per employee (RPE). $\mathrm{SED}_{i, t}$ represents the number of service-oriented business operations of consumer manufacturing enterprises. $X_{k}$ is the control variable set. Referring to existing studies, the following variables that have an important impact on enterprise performance are included: market monopoly degree (DMM) and labor factor structure (LES). $\gamma_{i}$ and $\lambda_{t}$ represent the nonobserved effects of enterprise and time, respectively, and $\varepsilon_{i, t}$ is a random disturbance term.

In order to investigate the nonlinear relationship between service-oriented manufacturing and enterprise performance and the situation of inflection point, based on equation (1), the quadratic term $\left(\mathrm{SED}^{2}\right)$ introducing serviceoriented manufacturing is further constructed as follows:

$$
\begin{aligned}
\operatorname{MP}_{i, t}\left(\mathrm{Rpe}_{i, t} ; \mathrm{Roa}_{i, t}\right)= & \alpha_{0}+\beta_{1} \operatorname{SED}_{i, t}+\beta_{2} \operatorname{SED}_{i, t}^{2}+\sum_{k} a_{k} X_{k} \\
& +\gamma_{i}+\lambda_{t}+\varepsilon_{i, t} .
\end{aligned}
$$

In order to better judge the appropriate model before formal estimation, we test the performance spillover effect of service-oriented manufacturing enterprises by using multilayer hybrid model. Firstly, the normality, Pearson coefficient, and VIF test of model variables are carried out to exclude the collinearity between variables. Secondly, the Ftest is used to select between different hybrid models. Finally, the choice between FEM and REM model is made by the Hausman test.

\section{Empirical Results}

4.1. Empirical Results of Total Samples. Model (1) in Table 2 is a mixed regression model. Model (2) adds a service-oriented quadratic term to model (1). Models (1) and (2) use revenue per employee (RPE) to test enterprise performance. The $F$ test and Hansen test support the selection of a better fixed effect model. The test results show that the coefficients of service are significant, and the quadratic coefficient of service is negative in the nonlinear relationship, showing an inverted " $U$ " curve relationship. Models (3) and (4) use the return on assets to represent enterprise performance. The test results show that there is a significant negative correlation between service-oriented manufacturing and enterprise performance. The service-oriented development of consumer manufacturing industry has a negative impact on the return on assets and falls into the "service trap." This also shows that China's consumer manufacturing enterprises are on the left side of the positive " $U$ " curve of service-oriented 
TABLE 2: Relationship between service and performance, by total sample.

\begin{tabular}{|c|c|c|c|c|}
\hline $\begin{array}{l}\text { Models } \\
\text { Variables }\end{array}$ & $\begin{array}{c}\text { Model } 1 \\
\text { RPE }\end{array}$ & $\begin{array}{c}\text { Model } 2 \\
\text { RPE }\end{array}$ & $\begin{array}{c}\text { Model } 3 \\
\text { ROA }\end{array}$ & $\begin{array}{c}\text { Model } 4 \\
\text { ROA }\end{array}$ \\
\hline SED & $\begin{array}{c}0.106^{* * *} \\
(0.028)\end{array}$ & $\begin{array}{c}0.347^{* * *} \\
(0.064)\end{array}$ & $\begin{array}{c}-0.029^{* * *} \\
(0.009) \\
\end{array}$ & $\begin{array}{c}-0.047^{* *} \\
(0.011)\end{array}$ \\
\hline $\mathrm{SED}^{2}$ & & $\begin{array}{c}-0.023^{* *} \\
(0.008)\end{array}$ & & $\begin{array}{c}0.008 \\
(0.038)\end{array}$ \\
\hline LES & $\begin{array}{c}0.004^{* * *} \\
(0.002)\end{array}$ & $\begin{array}{c}0.004^{* * *} \\
(0.002)\end{array}$ & $\begin{array}{c}0.013^{* * *} \\
(0.004)\end{array}$ & $\begin{array}{c}0.013^{* * *} \\
(0.004)\end{array}$ \\
\hline DMM & $\begin{array}{c}0.161^{* * *} \\
(0.026)\end{array}$ & $\begin{array}{c}0.190^{* * *} \\
(0.028) \\
\end{array}$ & $\begin{array}{c}0.153^{* * *} \\
(0.025) \\
\end{array}$ & $\begin{array}{c}0.148^{* * *} \\
(0.025)\end{array}$ \\
\hline EDS & $\begin{array}{c}0.006^{*} \\
(0.008)\end{array}$ & $\begin{array}{c}0.009 \\
(0.022) \\
\end{array}$ & $\begin{array}{c}0.039^{* *} \\
(0.011)\end{array}$ & $\begin{array}{c}0.081^{* * *} \\
(0.024)\end{array}$ \\
\hline CONS & $\begin{array}{c}0.775^{* * *} \\
(0.084) \\
\end{array}$ & $\begin{array}{c}0.654^{* * *} \\
(0.092) \\
\end{array}$ & $\begin{array}{c}0.194^{* * *} \\
(0.034)\end{array}$ & $\begin{array}{c}0.216^{* * *} \\
(0.032) \\
\end{array}$ \\
\hline Individual effect & Control & Control & Control & Control \\
\hline Time effect & Control & Control & Control & Control \\
\hline Adjusted $R^{2}$ & 0.211 & 0.288 & 0.147 & 0.128 \\
\hline Hansen & & 26.49 & 14.02 & 18.64 \\
\hline
\end{tabular}

Notes: ${ }^{* * *} p<0.01 .{ }^{* *} p<0.05 .{ }^{*} p<0.1$.

return on assets, and there is no inflection point, because the enterprise service degree of China's consumer manufacturing enterprises is generally low. In the early stage of service-oriented transformation, the intensification of competition and the increase of investment will lead to the decline of enterprise financial performance. Only when the service level of manufacturing industry matches its own production and management ability, can the financial performance of the manufacturing enterprises be significantly improved.

Of course, whether the subsample has an inflection point needs to be verified by industry. In the control variables, although the regression results of labor factor structure on enterprise performance are significant, the coefficient values are relatively small, indicating that the change of labor factor structure has a positive impact on performance but has little effect. The analysis shows that most of the basic consumer manufacturing industries we have selected are labor-intensive. The industry does not have high requirements for the knowledge reserve of enterprise employees. In addition, the market power of enterprises has an obvious positive effect on performance, and so does the scale of enterprises.

4.2. Empirical Test by Industry. Through the empirical test on the five consumption manufacturing subcategories, it is found that all the models pass the $F$-test and the Hansen test. The empirical estimation results are effective. Tables 3 and 4 , respectively, report the test results of the nonlinear relationship between service and performance.

The regression results are shown in Table 3. In models (1) and (2), the curve relationship between service-oriented manufacturing and RPE of clothing manufacturing enterprises has been tested. It is found that the first-order term coefficient of SED is significantly positive and the secondorder term coefficient is negative, showing a significant inverse " $U$ " curve relationship. In models (3) and (4), we mainly test the curve relationship between service-oriented manufacturing and return on assets of clothing manufacturing enterprises. It is found that there is a linear negative correlation between service-oriented manufacturing and return on assets. The service-oriented clothing manufacturing industry has a negative impact on the return on assets and falls into a "service trap." In general, the main conclusion of hypothesis 1 is supported.

In models (5) and (6), the service-RPE curve of electrical manufacturing enterprises has been tested. The results show that there is also a significant inverted " $U$ " curve relationship. In models (7) and (8), the service-ROA curve of electrical manufacturing enterprises has been tested. It is found that there is a linear negative correlation between service and ROA. The service of the electrical manufacturing industry has a negative impact on the initial ROA, resulting in a "service dilemma." It shows that the service-ROA curve of electrical appliance manufacturing enterprises is on the left side of the positive " $U$ " shape; there is no inflection point. Hypothesis $\mathrm{H} 1$ is further supported.

In models (9) and (10), the service-RPE curve of beverage and wine manufacturing enterprises has been tested. It is found that there is a linear positive correlation between service-oriented manufacturing and RPE, and there is no significant inverted " $U$ " relationship. In models (11) and (12), we have tested the service return curve relationship of beverage and wine manufacturing enterprises. It is found that there is a significant positive "U-shaped relationship" between service and return on assets. The service of beverage and wine manufacturing enterprises has a "service dilemma" for the return on assets in the short term, but it has jumped out of the "service trap" in the long term. Hypothesis H1 is basically supported.

In models (13) and (15) in Table 4, the coefficient of SED is not significant, indicating that there is no linear 
TABLE 3: The relationship between service and performance of consumer manufacturing enterprises, by industry (clothing, electrical appliances, and beverage).

\begin{tabular}{|c|c|c|c|c|c|c|c|c|c|c|}
\hline \multirow{3}{*}{$\begin{array}{l}\text { Models } \\
\text { Industries } \\
\text { Variables }\end{array}$} & Model 1 & Model 2 & Model 3 & Model 4 & Model 5 & Model 6 & Model 7 & Model 8 & Model 9 & Model 10 \\
\hline & \multicolumn{4}{|c|}{ Clothing manufacturing } & \multicolumn{4}{|c|}{ Electrical appliance manufacturing } & \multicolumn{2}{|c|}{$\begin{array}{l}\text { Beverage and wine } \\
\text { manufacturing }\end{array}$} \\
\hline & RPE & $\mathrm{RPE}$ & ROA & ROA & RPE & RPE & ROA & ROA & $\mathrm{RPE}$ & RPE \\
\hline SED & $\begin{array}{c}0.041^{* * *} \\
(0.010)\end{array}$ & $\begin{array}{c}0.254^{* * *} \\
(0.049)\end{array}$ & $\begin{array}{c}-0.027^{* * *} \\
(0.013)\end{array}$ & $\begin{array}{c}-0.018 \\
(0.041)\end{array}$ & $\begin{array}{c}0.072^{* * *} \\
(0.012)\end{array}$ & & $\begin{array}{c}-0.055^{* * *} \\
(0.009)\end{array}$ & & $\begin{array}{c}0.256^{* * *} \\
(0.076)\end{array}$ & $\begin{array}{c}0.048 \\
(0.094) \\
\end{array}$ \\
\hline $\mathrm{SED}^{2}$ & & $\begin{array}{c}-0.015^{* * *} \\
(0.004)\end{array}$ & & $\begin{array}{c}0.042 \\
(0.118)\end{array}$ & & $\begin{array}{c}-0.009^{* * *} \\
(0.005)\end{array}$ & & $\begin{array}{c}0.073 \\
(0.318)\end{array}$ & & \\
\hline LES & $\begin{array}{c}0.017^{* * *} \\
(0.003)\end{array}$ & $\begin{array}{c}0.017^{* * *} \\
(0.003)\end{array}$ & $\begin{array}{c}0.011^{* * *} \\
(0.000)\end{array}$ & $\begin{array}{c}0.011^{* * *} \\
(0.000)\end{array}$ & $\begin{array}{c}0.006^{* * *} \\
(0.001)\end{array}$ & $\begin{array}{c}0.007^{* * *} \\
(0.001)\end{array}$ & & $\begin{array}{c}0.008^{* * *} \\
(0.002)\end{array}$ & $\begin{array}{c}0.007^{* * *} \\
(0.002)\end{array}$ & $\begin{array}{c}0.007^{* * *} \\
(0.002)\end{array}$ \\
\hline DMM & $\begin{array}{c}0.160^{* * *} \\
(0.024)\end{array}$ & $\begin{array}{c}0.193^{* * *} \\
(0.025)\end{array}$ & $\begin{array}{c}0.473^{* * *} \\
(0.032)\end{array}$ & $\begin{array}{c}0.471^{* * *} \\
(0.033)\end{array}$ & $\begin{array}{c}0.620^{* * *} \\
(0.093)\end{array}$ & $\begin{array}{c}0.611^{* * *} \\
(0.093)\end{array}$ & $\begin{array}{c}0.321^{* * *} \\
(0.027)\end{array}$ & $\begin{array}{c}0.318^{* * *} \\
(0.027)\end{array}$ & $\begin{array}{c}0.511^{* * *} \\
(0.076)\end{array}$ & $\begin{array}{c}0.504^{* * *} \\
(0.077)\end{array}$ \\
\hline EDS & $\begin{array}{c}0.012^{*} \\
(0.006)\end{array}$ & $\begin{array}{c}0.009 \\
(0.022)\end{array}$ & $\begin{array}{c}0.010^{* *} \\
(0.007)\end{array}$ & $\begin{array}{c}0.021^{* * *} \\
(0.003)\end{array}$ & $\begin{array}{c}0.058^{*} \\
(0.022)\end{array}$ & $\begin{array}{c}0.083^{* * *} \\
(0.018)\end{array}$ & $\begin{array}{c}0.021^{*} \\
(0.018)\end{array}$ & $\begin{array}{c}0.016^{* * *} \\
(0.006)\end{array}$ & $\begin{array}{c}0.011^{* *} \\
(0.010)\end{array}$ & $\begin{array}{c}0.014 \\
(0.033)\end{array}$ \\
\hline CONS & $\begin{array}{c}0.900^{* * *} \\
(0.108)\end{array}$ & $\begin{array}{c}0.844^{* * *} \\
(0.126)\end{array}$ & $\begin{array}{c}0.528^{* * *} \\
(0.081)\end{array}$ & $\begin{array}{c}0.636^{* * *} \\
(0.093)\end{array}$ & $\begin{array}{c}0.779^{* * *} \\
(0.142)\end{array}$ & $\begin{array}{c}0.363^{* * *} \\
(0.149)\end{array}$ & $\begin{array}{l}1.174^{* * *} \\
(0.024)\end{array}$ & $\begin{array}{c}1.168^{* * *} \\
(0.021)\end{array}$ & $\begin{array}{c}0.595^{* * *} \\
(0.147)\end{array}$ & $\begin{array}{c}0.814^{* * *} \\
(0.095)\end{array}$ \\
\hline Individual effect & Control & Control & Control & Control & Control & Control & Control & Control & Control & Control \\
\hline Time effect & Control & Control & Control & Control & Control & Control & Control & Control & Control & Control \\
\hline Adjusted $R^{2}$ & 0.291 & 0.298 & 0.610 & 0.608 & 0.324 & 0.290 & 0.273 & 0.277 & 0.290 & 0.290 \\
\hline
\end{tabular}

Notes: ${ }^{* * *} p<0.01 .{ }^{* *} p<0.05 .{ }^{*} p<0.1$.

TABLE 4: Relationship between service and performance of consumer manufacturing enterprises, by industry (beverage, automobile, and medicine).

\begin{tabular}{|c|c|c|c|c|c|c|c|c|c|c|}
\hline \multirow{3}{*}{$\begin{array}{l}\text { Models } \\
\text { Industries } \\
\text { Variables }\end{array}$} & \multirow{2}{*}{\multicolumn{2}{|c|}{$\begin{array}{l}\text { Model } 11 \text { Model } 12 \\
\text { Beverage and wine } \\
\text { manufacturing }\end{array}$}} & Model 13 & Model 14 & Model 15 & Model 16 & Model 17 & Model 18 & Model 19 & Model 20 \\
\hline & & & \multicolumn{4}{|c|}{ Automobile manufacturing } & \multicolumn{4}{|c|}{ Medical and pharmaceutical manufacturing } \\
\hline & ROA & ROA & $\mathrm{RPE}$ & $\mathrm{RPE}$ & ROA & ROA & $\mathrm{RPE}$ & $\mathrm{RPE}$ & $\mathrm{ROA}$ & ROA \\
\hline SED & $\begin{array}{c}-0.032^{*} \\
(0.016)\end{array}$ & $\begin{array}{c}-0.153^{* * *} \\
(0.029)\end{array}$ & $\begin{array}{c}0.058 \\
(0.042) \\
\end{array}$ & $\begin{array}{c}0.551^{* * *} \\
(0.186)\end{array}$ & & & $\begin{array}{c}0.026 \\
(0.074) \\
\end{array}$ & & & $\begin{array}{c}0.009 \\
(0.027) \\
\end{array}$ \\
\hline $\mathrm{SED}^{2}$ & & $\begin{array}{c}0.012^{* *} \\
(0.006) \\
\end{array}$ & & $\begin{array}{c}-0.037^{* * *} \\
(0.009)\end{array}$ & & $\begin{array}{c}0.009^{* * *} \\
(0.003)\end{array}$ & & $\begin{array}{l}-0.002 \\
(0.004)\end{array}$ & & $\begin{array}{l}-0.084 \\
(0.218) \\
\end{array}$ \\
\hline LES & $\begin{array}{c}0.013^{* * *} \\
(0.005)\end{array}$ & $\begin{array}{c}0.013^{* * *} \\
(0.005)\end{array}$ & $\begin{array}{c}0.010^{* * *} \\
(0.007)\end{array}$ & $\begin{array}{c}0.010^{* * *} \\
(0.007)\end{array}$ & $\begin{array}{c}0.014^{* *} \\
(0.011)\end{array}$ & & $\begin{array}{c}0.002^{* * *} \\
(0.001)\end{array}$ & & & \\
\hline DMM & $\begin{array}{c}0.401^{* * *} \\
(0.034)\end{array}$ & $\begin{array}{c}0.399^{* * *} \\
(0.027)\end{array}$ & $\begin{array}{c}0.668^{* * *} \\
(0.137)\end{array}$ & $\begin{array}{c}0.557^{* * *} \\
(0.140)\end{array}$ & $\begin{array}{c}0.188^{* * *} \\
(0.032)\end{array}$ & & $\begin{array}{c}0.644^{* * *} \\
(0.048)\end{array}$ & $\begin{array}{c}0.743^{* * *} \\
(0.048)\end{array}$ & $\begin{array}{c}0.754 \\
(0.053)\end{array}$ & $\begin{array}{c}0.754^{* * *} \\
(0.053)\end{array}$ \\
\hline EDS & $\begin{array}{c}0.001 \\
(0.034) \\
\end{array}$ & $\begin{array}{c}0.004 \\
(0.046) \\
\end{array}$ & $\begin{array}{c}0.044^{* * *} \\
(0.012) \\
\end{array}$ & $\begin{array}{c}0.042^{* * *} \\
(0.010) \\
\end{array}$ & $\begin{array}{c}0.188^{* * *} \\
(0.029) \\
\end{array}$ & $\begin{array}{c}0.013^{* *} \\
(0.010) \\
\end{array}$ & $\begin{array}{c}0.009^{* *} \\
(0.006) \\
\end{array}$ & $\begin{array}{c}0.009^{* *} \\
(0.006) \\
\end{array}$ & $\begin{array}{c}0.047^{* * *} \\
(0.009) \\
\end{array}$ & $\begin{array}{c}0.071^{* * *} \\
(0.013) \\
\end{array}$ \\
\hline CONS & $\begin{array}{c}1.021^{* * *} \\
(0.103)\end{array}$ & $\begin{array}{c}1.147^{* * *} \\
(0.084)\end{array}$ & $\begin{array}{c}0.782^{* *} \\
(0.092)\end{array}$ & $\begin{array}{c}1.538^{* * *} \\
(0.121)\end{array}$ & $\begin{array}{c}0.473^{* * *} \\
(0.029)\end{array}$ & $\begin{array}{c}0.223^{* *} \\
(0.146)\end{array}$ & $\begin{array}{c}1.135^{* * *} \\
(0.037)\end{array}$ & $\begin{array}{c}1.073^{* * *} \\
(0.124)\end{array}$ & $\begin{array}{c}0.128^{* * *} \\
(0.012)\end{array}$ & $\begin{array}{c}0.197^{* * *} \\
(0.039)\end{array}$ \\
\hline Individual effect & Control & Control & Control & Control & Control & Control & Control & Control & Control & Control \\
\hline Time effect & Control & Control & Control & Control & Control & Control & Control & Control & Control & Control \\
\hline Adjusted $R^{2}$ & 0.640 & 0.647 & 0.331 & 0.363 & 0.200 & 0.228 & 0.235 & 0.230 & 0.358 & 0.374 \\
\hline
\end{tabular}

Notes: ${ }^{* * *} p<0.01 .{ }^{* *} p<0.05 .{ }^{*} p<0.1$.

relationship between SED and enterprise performance in automobile manufacturing industry. In the results of model (14), the primary term coefficient is significantly positive at the $1 \%$ statistical level, while the value of quadratic term coefficient is significantly negative, indicating that there is an inverted " $U$ " characteristic between the SED and RPE in automobile manufacturing enterprises. In model (16), the primary term coefficient of SED is significantly negative and the secondary term coefficient is significantly positive. There is a significant positive " $U$ " relationship between the SED and ROA in automobile manufacturing enterprises, which also shows that the service level of automobile manufacturing enterprises in China is high and there has been an inflection point, and they have fallen into the "principal-agent trap" in the service-RPE curve, but in the service-ROE curve, the "service-oriented trap" has been jumped out. Here hypothesis 1 is tested. The coefficient of SED in models (17)-(20) is not significant in the four 
models, indicating that the service-oriented strategy of pharmaceutical enterprises does not promote or inhibit enterprise performance.

\section{Further Empirical Analysis: Scenario Test and Internal Mechanism}

5.1. Scenario Test of Different Attributes. In order to analyze the reasons for the difference of service performance curve in different consumption types of manufacturing industry, this paper makes a scenario test from two different attributes: industry technical level and competition degree. The empirical results show that, at a certain industry technical level, the manufacturing industry with relatively low technical complexity is more prone to the inflection point of the service performance curve; at a certain industry competition level, the manufacturing industry with relatively high industry competition is more prone to the inflection point of the service performance curve. According to the results reported in Tables 3 and 4, the shape and inflection point of the "service performance" curve are summarized. Referring to Liu et al. [38], the complete consumption coefficient of manufacturing service is used to represent the technical complexity of consumer manufacturing industry, and the Herfindahl-Hirschman Index (HHI) is used to represent the industrial competitiveness of five types of consumer manufacturing industry. The calculation results are shown in Table 5. The technical complexity of electrical appliances and automobile manufacturing industry is relatively close, but the automobile manufacturing industry has reached an inflection point before the electrical appliances manufacturing industry. This is because the industry competitiveness of the automobile manufacturing industry is 0.16 , which is greater than that of the electrical manufacturing industry. Coincidentally, for the beverage and wine manufacturing industry and automobile manufacturing industry with close industry competition, the industrial technical complexity value of beverage and the wine manufacturing industry is 0.34 , which is significantly less than the automobile manufacturing industry, while the beverage and wine manufacturing industry has an inflection point at the service index of 5.92, leading the automobile manufacturing industry by 7.45 . Due to the fierce competition in the clothing manufacturing industry, there is a service dilemma in the service-ROA curve, but there is no inflection point. Due to the high technical complexity and small competition, the pharmaceutical manufacturing industry does not show the obvious " $U$ " relationship between service and performance. Hypothesis 2 is basically proved.

5.2. Internal Mechanism Analysis. The technical level and competition degree of the industry directly reflect the input of service elements by consumer manufacturing enterprises, at both ends of the R\&D design and market of the value chain. Consumer manufacturing enterprises increased service-oriented investment during the sample period and modified their business scope. According to different factors, the increased service-oriented investment is divided into 10 categories: e-commerce, consulting and training, design and $\mathrm{R} \& \mathrm{D}$, finance, consignment, contracted operation, aftersales, export and import, leasing, and logistics warehousing. The increased technical level of service-oriented investment is calculated by using the export technical complexity index. The results show that e-commerce, commission sales, contracted operation, after-sales, import and export, leasing, logistics, and warehousing belong to low-end service, which reflects the market end of the industrial value chain, and consulting, training, design, $\mathrm{R} \& \mathrm{D}$, and finance belong to medium- and high-end service, which reflects the R\&D and design end of the industrial value chain. The details of service types and proportion of consumer manufacturing subenterprises in 2011 and 2019 are shown in Table 6. The five types of consumer manufacturing industries have strengthened the technical support of medium- and highend services, such as consulting and training, design and $\mathrm{R} \& \mathrm{D}$, and financial investment, and also increased service investment in contracting operation and leasing, so as to enhance market competitiveness.

Among them, clothing manufacturing enterprises mainly increased service investment in contracted operation, consulting and training, leasing, finance, and R\&D and design. Contracted operation services increased the most, from $36 \%$ in 2011 to $82 \%$ in 2019 , indicating that clothing manufacturing focused relatively on increasing low-end services. In practice, after 2011, the clothing industry is facing the recession of the international market and the impact of the domestic online sales model. In addition, consumers begin to pay attention to quality consumption and pursue personalized and differentiated services. Clothing manufacturing enterprises are forced to transform into flexible and intelligent manufacturing [39].

Electrical manufacturing enterprises have increased a lot in contracting operation, leasing, consulting and training, design and $\mathrm{R} \& \mathrm{D}$, and other services, of which design and R\&D will increase to $100 \%$ by 2019 , indicating that, in electrical manufacturing enterprises, $\mathrm{R} \& \mathrm{D}$ and market are equally important, low-end service technologies as well as medium- and high-end service technologies. Electrical appliance manufacturing enterprises have introduced new technologies and expanded online sales channels, which are conducive to expanding sales and increasing per employee income, but at the same time, the management cost has increased significantly, resulting in a negative correlation in the "service return on assets" curve.

Beverage and wine manufacturing enterprises have the largest growth in logistics and warehousing services, from $28 \%$ in 2011 to $49 \%$ in 2019 . They also focus on increasing low-end services and expanding the market. In practice, after 2011, beverage and wine manufacturing enterprises mainly increased service businesses, such as network marketing, logistics and transportation, catering and entertainment investment, and business exhibition. The beverage and wine manufacturing industry is a traditional industry. Its product iteration speed is slow, its demand for R\&D is not high, and its impact on external shocks is not large. The service business focuses on the related nodes in the industrial chain, which not only reduces the transaction cost, but also 
TABLE 5: The "service performance" curve of consumer manufacturing industry, by attributes.

\begin{tabular}{|c|c|c|c|c|c|}
\hline Industries & $\begin{array}{l}\text { Service-oriented revenue per } \\
\text { employee }\end{array}$ & $\begin{array}{c}\text { Service-oriented return on } \\
\text { assets }\end{array}$ & $\begin{array}{c}\text { Points of } \\
\text { inflection (SED- } \\
\text { RPE; SED-ROA) }\end{array}$ & $\begin{array}{c}\text { Industry } \\
\text { technical } \\
\text { complexity }\end{array}$ & $\begin{array}{c}\text { Degree of } \\
\text { industry } \\
\text { competition }\end{array}$ \\
\hline $\begin{array}{l}\text { Clothing } \\
\text { manufacturing }\end{array}$ & $\begin{array}{l}\text { Inverted U-shaped relation } \\
\text { (short-term service spillover; } \\
\text { long-term service dilemma) }\end{array}$ & $\begin{array}{l}\text { Linear negative correlation } \\
\text { (service trap) }\end{array}$ & $\begin{array}{l}\text { (8.47; no } \\
\text { inflection point) }\end{array}$ & 0.37 & 0.28 \\
\hline $\begin{array}{l}\text { Electrical appliance } \\
\text { manufacturing }\end{array}$ & $\begin{array}{l}\text { Inverted U-shaped relation } \\
\text { (short-term service spillover; } \\
\text { long-term service dilemma) }\end{array}$ & $\begin{array}{c}\text { Linear negative correlation } \\
\text { (service trap) }\end{array}$ & $\begin{array}{l}\text { (7.28; no } \\
\text { inflection point) }\end{array}$ & 0.49 & 0.09 \\
\hline $\begin{array}{l}\text { Beverage and wine } \\
\text { manufacturing }\end{array}$ & $\begin{array}{l}\text { Linear positive correlation } \\
\quad \text { (service spillover) }\end{array}$ & $\begin{array}{l}\text { Positive U-shaped relation } \\
\text { (short-term service trap; } \\
\text { long-term service spillover) }\end{array}$ & $\begin{array}{l}\text { (no inflection } \\
\text { point; } 5.92 \text { ) }\end{array}$ & 0.34 & 0.11 \\
\hline $\begin{array}{l}\text { Automobile } \\
\text { manufacturing }\end{array}$ & $\begin{array}{l}\text { Inverted U-shaped relation } \\
\text { (short-term service spillover; } \\
\text { long-term service dilemma) }\end{array}$ & $\begin{array}{l}\text { Positive U-shaped relation } \\
\text { (short-term service trap; } \\
\text { long-term service spillover) }\end{array}$ & $(7.45 ; 6.89)$ & 0.51 & 0.16 \\
\hline $\begin{array}{l}\text { Medical and } \\
\text { pharmaceutical } \\
\text { manufacturing }\end{array}$ & $\begin{array}{l}\text { No linear relationship \& no } \\
\text { U-shaped relationship }\end{array}$ & $\begin{array}{l}\text { No linear relationship \& no } \\
\text { U-shaped relationship }\end{array}$ & $\begin{array}{l}\text { (no inflection } \\
\text { point; no } \\
\text { inflection point) }\end{array}$ & 0.46 & 0.02 \\
\hline
\end{tabular}

TABLE 6: Types and proportion of services provided by manufacturing enterprises, by type.

\begin{tabular}{|c|c|c|c|c|c|c|c|c|c|c|c|}
\hline Industries & $\begin{array}{l}\text { Year/ } \\
\text { type }\end{array}$ & $\begin{array}{c}\text { Consulting } \\
\text { training } \\
(\%)\end{array}$ & $\begin{array}{c}\text { Design } \\
\text { and } \\
\text { R\&D } \\
(\%)\end{array}$ & $\begin{array}{c}\text { Finance } \\
(\%)\end{array}$ & $\begin{array}{c}\text { Electronic } \\
\text { commerce } \\
(\%)\end{array}$ & $\begin{array}{c}\text { Consignment } \\
(\%)\end{array}$ & $\begin{array}{c}\text { Contracted } \\
\text { operation } \\
(\%)\end{array}$ & $\begin{array}{l}\text { After- } \\
\text { sale } \\
\text { service } \\
(\%)\end{array}$ & $\begin{array}{c}\text { Lease } \\
(\%)\end{array}$ & $\begin{array}{c}\text { Export } \\
\text { and } \\
\text { import } \\
(\%)\end{array}$ & $\begin{array}{c}\text { Logistics } \\
\text { storage } \\
(\%)\end{array}$ \\
\hline \multirow{2}{*}{$\begin{array}{l}\text { Clothing } \\
\text { manufacturing }\end{array}$} & 2011 & 64 & 84 & 24 & 92 & 40 & 28 & 56 & 28 & 84 & 36 \\
\hline & 2019 & 69 & 88 & 34 & 92 & 58 & 56 & 60 & 41 & 88 & 46 \\
\hline \multirow{2}{*}{$\begin{array}{l}\text { Electrical } \\
\text { appliance } \\
\text { manufacturing }\end{array}$} & 2011 & 49 & 96 & 16 & 100 & 10 & 25 & 27 & 8 & 83 & 4 \\
\hline & 2019 & 80 & 100 & 35 & 100 & 15 & 60 & 38 & 44 & 82 & 19 \\
\hline \multirow{2}{*}{$\begin{array}{l}\text { Beverage and } \\
\text { wine } \\
\text { manufacturing }\end{array}$} & 2011 & 42 & 88 & 27 & 96 & 54 & 36 & 4 & 27 & 92 & 23 \\
\hline & 2019 & 69 & 92 & 47 & 96 & 54 & 81 & 10 & 52 & 92 & 25 \\
\hline \multirow{2}{*}{$\begin{array}{l}\text { Automobile } \\
\text { manufacturing }\end{array}$} & 2011 & 24 & 55 & 24 & 97 & 52 & 28 & 0 & 24 & 66 & 28 \\
\hline & 2019 & 42 & 59 & 33 & 100 & 51 & 36 & 2 & 31 & 72 & 49 \\
\hline \multirow{2}{*}{$\begin{array}{l}\text { Medical and } \\
\text { pharmaceutical } \\
\text { manufacturing }\end{array}$} & 2011 & 54 & 66 & 15 & 92 & 18 & 16 & 2 & 13 & 72 & 12 \\
\hline & 2019 & 62 & 71 & 22 & 93 & 24 & 31 & 8 & 26 & 79 & 23 \\
\hline
\end{tabular}

Notes: It is to manually code and classify the business scope of A-share consumer manufacturing enterprises. See the description of service level index construction for coding rules.

improves the overall interests and market competitiveness of enterprises. Therefore, the beverage and wine manufacturing industry has crossed the "service trap" and ushered in a new era "service, return on assets." The curve is positively related to the benefit stage.

Automobile manufacturing enterprises have increased a lot in contracted operation, consignment, after-sales, leasing, logistics warehousing, investment, and other services, among which contracted operation has increased the most, from $28 \%$ in 2011 to $56 \%$ in 2019 . It shows that automobile manufacturing has relatively focused on increasing low-end services. In practice, after 2011, automobile manufacturing enterprises have mainly increased service businesses as follows: Computer software development, finance, leasing, insurance, tourism, consulting, auto repair, chain operation, agency service, etc. There are both "service trap" and "principal-agent dilemma" in the automotive industry. The main reason is that, in addition to the production business, automobile enterprises invest a lot in software development, tourism, leasing, and other new businesses that are less related to their own advantageous fields.

The overall rise of pharmaceutical manufacturing enterprises in the service industry is not obvious, but consulting and training, design, R\&D, e-commerce, and export and import are maintained at a high proportion, indicating that pharmaceutical manufacturing enterprises pay equal attention to R\&D and market, and low-end service technologies as well as medium- and high-end service technologies. Due to the small elasticity of medical demand, the pharmaceutical manufacturing industry is less affected by macroeconomic fluctuations [40]. Although service-oriented manufacturing is implemented based on the industrial value chain, the impact of service-oriented strategy on the performance of pharmaceutical enterprises is not obvious, 
due to large R\&D investment, long industrialization cycle, and high $\mathrm{R} \& \mathrm{D}$ risk, coupled with the increase of management cost.

\section{Conclusions and Recommendations}

6.1. Main Conclusions. The main conclusions of this study are as follows: (1) there are great differences in service performance curves of consumer manufacturing enterprises in different industries and different performance objectives. Among them, there is a significant positive " $U$ " relationship between service and ROA in the automobile manufacturing industry, while there is a significant inverted " $U$ " relationship between service and RPE. In the beverage and wine manufacturing industry, there is a positive " $U$ " inflection point in the service-ROA curve, but there is only a linear relationship between service and RPE. There is a "service dilemma" in the service-ROA curve of clothing and electrical appliances and no inflection point. The impact of serviceoriented strategy on the performance of pharmaceutical enterprises is not obvious. (2) Due to the different technical levels and competitive environment of different consumer manufacturing industries, the inflection point of "service performance" curve shows obvious differences. At a certain industry technical level, it is easier for consumer manufacturing enterprises with relatively low technical complexity to get rid of the "service dilemma." At a certain industry competition level, it is easier for consumer manufacturing enterprises with relatively high industry competition to get rid of the "service dilemma," but also face the "principal-agent dilemma" earlier. (3) The causes of "service-oriented trap" in clothing and electrical appliance manufacturing industry are similar. The obstacles come from the great impact of the Internet and the high cost of online channel construction. The "service dilemma" and "principal-agent dilemma" of the automotive industry are more because they do not follow the correlation law of the industrial value chain and invest in software development and other fields that are not related to their own advantages and the principal-agent problems of management. The beverage and wine manufacturing industry has little technical difficulty and pays attention to broadening channels and enhancing market competitiveness, which is relatively easy to cross the "service trap."

6.2. Practical Implications. The service of basic manufacturing is the key to leading the country's manufacturing industry to become advanced. Although the service-oriented strategy of consumer goods manufacturing has a positive impact on commodity value, customer stickiness, and scope economy, the service-oriented performance effect is not achieved overnight. In this regard, we put forward the following suggestions: Firstly, consumer goods manufacturing enterprises should explore the growth point of the integration of manufacturing and service industry from the perspective of industrial value chain correlation, fully consider the differences in technical complexity and market competition in the industrial environment, and rationally expand the scope of serviceoriented business. Secondly, for consumer manufacturing enterprises that have approached or crossed the "service trap," they should actively integrate advantageous resources, extend services on products, and strengthen front-end product research and manufacturing e-commerce services, so as to prolong the product life cycle, create value services, and obtain customer stickiness; thirdly, consumer manufacturing enterprises are still in the early stage of service-oriented manufacturing and need to reserve enough knowledge and capital to quickly adapt to the new market, to give full play to the synergy of various departments, and to avoid or cross the "service-oriented trap." Fourthly, improve the incentive and restraint mechanism of enterprise executives to avoid the "principal-agent dilemma." Finally, we should adhere to the new manufacturing development model of "manufacturing + network + service" and at the same time, encourage and guide the manufacturing industry to develop professional services and value-added services such as software development, warehousing and logistics, maintenance support, and e-commerce, to improve enterprise performance.

\section{Data Availability}

The data used for this study are available and would be supplied upon request.

\section{Conflicts of Interest}

The authors declare no conflicts of interest.

\section{Authors' Contributions}

All the authors contributed equally to this work.

\section{Acknowledgments}

This work was supported by the NSFC project "field experimental study on the impact of digital inequality on belief bias, willingness to compete, and income" (no. 72063035) and fund project of Yunnan Science and Technology Department "financial mismatch, innovation sustainability, and enterprise performance" (2019FD117).

\section{References}

[1] S. Vandermerwe and J. Rada, "Servitization of business: adding value by adding services," European Management Journal, vol. 6, no. 4, pp. 314-324, 1988.

[2] M. Antioco, R. K. Moenaert, A. Lindgreen, and M. G. M. Wetzels, "Organizational antecedents to and consequences of service business orientations in manufacturing companies," Journal of the Academy of Marketing Science, vol. 36, no. 3, pp. 337-358, 2008.

[3] J. X. Chen, "An empirical test of the effect of manufacturing service-orientation on corporate performance: a comparison between Chinese and American enterprises," Journal of Business Economics, vol. 2, no. 4, pp. 33-41, 2010. 
[4] H. Gebauer, E. Fleisch, and T. Friedli, "Overcoming the service paradox in manufacturing companies," European Management Journal, vol. 23, no. 1, pp. 14-26, 2005.

[5] Z. L. Wei and F. B. Wang, "Influence of servitization in manufacturing on enterprise performance-PSM-DID empirical analysis based on the data of listed companies in Guangdong province," Journal of Finance and Economics Theory, vol. 5, no. 6, pp. 72-86, 2020.

[6] V. Mathieu, "Service strategies within the manufacturing sector: benefits, costs and partnership," International Journal of Service Industry Management, vol. 12, no. 5, pp. 451-475, 2001.

[7] Y. Xing, Y. Liu, S. Tarba, and S. Cooper, "Servitization in mergers and acquisitions: manufacturing firms venturing from emerging markets into advanced economies," International Journal of Production Economics, vol. 316, Article ID 303899, 2016.

[8] A. Neely, "Exploring the financial consequences of the servitization of manufacturing," Operations Management Research, vol. 1, no. 2, pp. 103-118, 2009.

[9] R. Oliva and R. Kallenberg, "Managing the transition from products to services," International Journal of Service Industry Management, vol. 14, no. 2, pp. 160-172, 2003.

[10] T. Xiao, Q. Nie, and H. Liu, "Examination study to the impact of manufacturing sub-sector servitisation on the enterprise performance," Science of Science and Management of S.\&T.vol. 35, no. 4, pp. 154-162, 2014.

[11] C. Watanabe and J. Y. Hur, "Firm strategy in shifting to service-oriented manufacturing: the case of Japan's electrical machinery industry," Journal of Services Research, vol. 124, no. 5, pp. 6-22, 2014.

[12] L. Zhen, "An analytical study on service-oriented manufacturing strategies," International Journal of Production Economics, vol. 139, no. 1, pp. 220-228, 2012.

[13] A. Bikfalvi, G. Lay, S. Maloca, and B. R. Waser, "Servitization and networking: large-scale survey findings on product-related services,” Service Business, vol. 7, no. 1, pp. 61-82, 2013.

[14] Y. T. Peng, D. Xu, Y. Ya Li, and K. Wang, "A product service supply chain network equilibrium model considering capacity constraints," Mathematical Problems in Engineering, vol. 2020, Article ID 1295072, 15 pages, 2020.

[15] C. P. Hu, X. L Ran, and Q. F. Hu, "Service provision and performance of manufacturing enterprises: the moderating effect of customer-centered orientation," Technology Economics, vol. 38, no. 11, pp. 64-73, 2019.

[16] J. Florin, M. Bradford, and D. Pagach, "Information technology outsourcing and organizational restructuring: an explanation of their effects on firm value," The Journal of High Technology Management Research, vol. 16, no. 2, pp. 241-253, 2005.

[17] Z. Jiang and N. Li, "The impact of service innovation and manufacturing service on enterprise performance," Science Research Management, vol. 36, no. 5, pp. 29-37, 2015.

[18] Z. Weng, H. A. Wang, and P. Wang, "The effect of service transition on company values," Finance \& Trade Economics, vol. 100, no. 2, pp. 117-123, 2010.

[19] T. Xiao, "Can Chinese manufacturing get performance dividend through servitization," Finance \& Trade Economics, vol. 39, no. 3, pp. 138-153, 2018.

[20] M. Kohtamäki, J. Partanen, V. Parida, and J. Wincent, "Nonlinear relationship between industrial service offering and sales growth: the moderating role of network capabilities," Industrial Marketing Management, vol. 42, no. 8, pp. 13741385, 2013.
[21] F. F. Suarez, M. A. Cusumano, and S. J. Kahl, "Services and the business models of product firms: an empirical analysis of the software industry," Management Science, vol. 59, no. 2, pp. 420-435, 2013.

[22] M. Crozet and E. Milet, "Should everybody be in services? The effect of servitization on manufacturing firm performance," Journal of Economics \& Management Strategy, vol. 127, no. 1, pp. 2-33, 2017.

[23] A. Eggert, J. Hogreve, W. Ulaga, and E. Muenkhoff, "Industrial services, product innovations, and firm profitability: a multiple-group latent growth curve analysis," Industrial Marketing Management, vol. 40, no. 5, pp. 661-670, 2011.

[24] E. Fang, R. W. Palmatier, and J.-B. E. M. Steenkamp, "Effect of service transition strategies on firm value," Journal of Marketing, vol. 72, no. 5, pp. 1-14, 2008.

[25] G. S. Hansen and B. Wernerfelt, "Determinants of firm performance: the relative importance of economic and organizational factors," Strategic Management Journal, vol. 10, no. 5, pp. 399-411, 1989.

[26] Y. P. Zhao, R. R. Pan, J. Q. Luo, Y. F. Wang, and Z. C. Yang, "Research on the relationship between China's servitization of manufacturing and enterprise performance from the perspective of industrial environment," Soft Science, vol. 35, no. 3, pp. 8-14, 2021.

[27] S. A. Khan, D. Qianli, W. SongBo, K. Zaman, and Y. Zhang, "Environmental logistics performance indicators affecting per capita income and sectoral growth: evidence from a panel of selected global ranked logistics countries," Environmental Science and Pollution Research International, vol. 24, no. 2, pp. 1518-1531, 2017.

[28] A. Neely, O. Benedtinni, and I. Visnjic, "The servitization of manufacturing: further evidence," in Proceedings of the 14th European Operations Management Association Conference, University of Cambridge, Cambridge, England, July 2011.

[29] T. Robinson, C. M. Clarke-Hill, and R. Clarkson, "Differentiation through service: a perspective from the commodity chemicals sector," The Service Industries Journal, vol. 22, no. 3, pp. 149-166, 2002.

[30] L. Ambroise, I. Prim-Allaz, and C. Teyssier, "Financial performance of servitized manufacturing firms: a configuration issue between servitization strategies and customer-oriented organizational design," Industrial Marketing Management, vol. 71, no. 5, pp. 54-68, 2018.

[31] Q. Xia and Z. L. Hu, "Can servitization of manufacturing input improve total factor productivity? From the perspective of cost and risks," Contemporary Finance \& Economics, vol. 7, no. 7, pp. 99-111, 2018.

[32] D. Vladimirova, "Made to serve. How manufacturers can compete through servitization and product-service systems," Production Planning \& Control, vol. 26, no. 10, pp. 839-840, 2014.

[33] X. Dai, Z. Li, and Y. Zhang, "Differences in service input sources, manufacturing servitization and GVC upgrading," Journal of Finance and Economics, vol. 45, no. 5, pp. 30-43, 2019.

[34] T. Baines, H. Lightfoot, P. Smart, and S. Fletcher, "Servitization of the manufacturing firm: exploring the operations practices and technologies that deliver advanced services," International Journal of Operations \& Production Management, vol. 34, no. 1, pp. 2-35, 2014.

[35] I. V. Kastalli and B. Van Looy, "Servitization: disentangling the impact of service business model innovation on manufacturing firm performance," Journal of Operations Management, vol. 31, no. 4, pp. 169-180, 2013. 
[36] L. F. Alrneida, P. A. Miguel, and M. Terra, "A literature review of servitization: a preliminary analysis," in Proceedings of the POMS 19th Annual Conference, La Jolla, CA, USA, May 2008.

[37] Y. Zhang, "Product market power, corporate governance and the information content of stock price," South China Journal of Economics, vol. 24, no. 12, pp. 26-40, 2011.

[38] B. Liu, Q. Wei, Y. Lv, and K. F. Zhu, "Service oriented manufacturing industry and value chain upgrading," Economic Research Journal, vol. 51, no. 3, pp. 151-162, 2016.

[39] X. H. Wang, Y. G. Wu, and L. Liang, "A new business mode for $\mathrm{fts}$ chain in an e-commerce environment," Mathematical Problems in Engineering, vol. 2014, Article ID 675414, 2014.

[40] M. Drummond, R. Frans Rutten, B. Antonio et al., "Economic evaluation of pharmaceuticals: a european perspective," PharmacoEconomics, vol. 1, no. 5, pp. 161-162, 1993. 